\title{
Teaching methods and educability motors: Effectiveness in improving long-jump skills
}

\author{
Ida Zubaida ${ }^{1, *(\mathbb{C}}$, Ade Tuti Lestari ${ }^{2}{ }^{(\mathbb{0}}$, Bachtiar $^{3}{ }^{(\mathbb{C}}$ \\ Universitas Sultan Ageng Tirtayasa, Indonesia ${ }^{1}$ \\ STKIP Situs Banten, Indonesia ${ }^{2}$ \\ Universitas Muhammadiyah Sukabumi, Indonesia ${ }^{3}$
}

Received: 13 July 2020; Accepted 19 January 2021; Published 09 February 2021

Ed 2021; 6(1): 59-66

\begin{abstract}
This study investigates the differences in exercise teaching methods, commando teaching methods and motor skills on long jump skills. This research is conducted at SMP Negeri 17 Serang, Banten Province. The research design uses a 2 X 2 factorial. A random cluster technique is used in sampling. The number of samples taken is 40 students divided into four groups, each consisting of 10 students who are separated using the Verducci technique. Analysis of Variance (ANOVA) in two ways is used in analyzing the data and continued with the Tukey test with a significance level of a $=0.05$, with the results: (1) overall there is a difference in the effect between the training style teaching method and the command style on long jump skills, (2) students who have high motor educability, the exercise style teaching method is better than the command style teaching method for long jump skills, (3) there is no significant difference in students who have low motor ability to the command style teaching method with the exercise style teaching method learning outcomes long jump skills, (4) there is a positive interaction between teaching methods and motor skills for long jump skills. This research needs to be followed up in the future to provide input to teachers and researchers. If you want to measure the motor ability of long jump learning, you can use the training teaching method to get maximum results.
\end{abstract}

Keywords: Teaching method; command style; training style; motor educability; long jump

https://doi.org/10.25299/sportarea.2021.vol6(1).5274

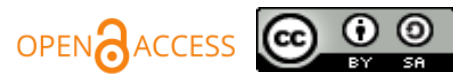

Copyright @ 2021 Ida Zubaida, Ade Tuti Lestari, Bachtiar

Corresponding author: Ida Zubaida, Physical Education Health and Recreation, Universitas Sultan Ageng Tirtayasa, Serang, Banten, Indonesia

Email: ida.zubaida@untirta.ac.id

How To Cite: Zubaidah, I., Lestari, A. T., \& Bachtiar. (2021). Teaching methods and educability motors: Effectiveness in improving long-jump skills. Journal Sport Area, 6(1), 59-66. https://doi.org/10.25299/sportarea.2021.vol6(1).5274

\section{INTRODUCTION}

The locomotor motion taught in schools in physical education subjects aims to improve students' basic motor skills. One of the materials about basic motion is in learning long jump in athletics. In the long jump material, it is taught in sub-sections and carried out continuously according to the stages according to the opinion Ahmad Atiq in Iswandi, Kaswari, and Purnomo (2013) long jump consists of several elements, namely: prefix, support, hovering and landing. In addition, in practicing long jump, other elements must also be considered in influencing the results of the jump, one of which is according to Huda (2012) namely biomotor abilities (speed, strength, endurance, explosive agility, flexibility, coordination and accuracy).

The role of physical education in schools is very important for the development of motor, cognitive and affective skills. In the cognitive theory, it explains that the function of organisms and their environment affects human behavior, this shows how important the influence of these two factors is in obtaining 
maximum learning outcomes (Juniar \& Iskandar, 2018). Through the learning process and the development of physical education in schools, it is hoped that students can gain experiences that are closely related to learning the motion they learn either from educators, from friends or from their own discoveries (Agam, Rahayu, \& Rifai, 2016), whereas according to opinion Sutikno (2014) stated that learning itself is all efforts that must be made by all educators so that the interaction of the learning process occurs in each student. Where the achievement of each learning process is determined by the teaching style of each teacher. There are several teaching styles that can be applied in the learning process according to Mosston in Rizal and Kasriman (2020) namely, a) command style, b) practice style, c) reciprocal style, d) self-check style, e) inclusion style, f) guide discovery style, g) divergent style and h) individual program learners design. In this study, one of them discusses the command style teaching and exercise teaching style.

Research result of Fallo (2016) found in the field many physical education teachers still use the command-style learning method because they think that with the command style students will more easily absorb the learning results Rahayu (2013) explained that, the commando teaching style has a characteristic where all decisions are controlled by the teacher. In line with opinion Paturusi (2012) that the command style is a learning approach that is very dependent on the teacher. In fact, every student has critical thinking and curiosity, far from what is only explained by the teacher, so that the command style is felt to be less developing student potential. While the exercise teaching style is a learning approach in the form of exercises that are carried out sequentially and repeatedly (Rahayu et al., 2017), this teaching style is intended to find an answer to technical skills. The teaching style applied in long jumping must be in accordance with the characteristics of the teaching style or method in physical education.

The basic competencies contained in physical education include practicing basic movement activities in athletic sports, both locomotor and manipulative skills, such as: running, jumping, throwing and rejecting. This must be supported by good coaching through a learning process supported by competent teaching staff and supported by appropriate sports facilities and infrastructure (Imansyah, 2019), become the researcher's consideration to use a commando learning style approach in teaching the long jump. In the process of implementing the long jump with the training teaching method and the commando teaching method, other supporting abilities are needed, namely good motor ability, in order to produce long jumps.

The term motor educability is introduced into the physical education literature by McCloy in 1934 and is defined as the ability to develop high skills quickly. According to Aryanti (2019) there are 2 potential movement abilities in learning motion which are heavily influenced by hereditary factors (heredity), namely motor ability (ability to move) and motor ability (ability to learn motion) which means a person's ability to learn new movements. According to Candra and Hidayah, (2015) physical ability is one of the internal factors that affect a person's appearance both in skill movement and competition. This is related to motor ability which can be defined as how fast a person is in mastering a new skill carefully. The ability to move will continue to increase if it is supported in terms of good physical characteristics.

The various kinds of physical characteristics and maturity are developed, according to Sujana, Muhtar, \& Nuryadi (2014) an individual will always develop his skills to form movement skills, both of game and sport skills. According to Sumantri, Sulaiman, and Nasuka (2016) choosing the right teaching style is the key to the success of a teacher in providing learning for students, motor ability in students during the physical education learning process has a major role as the basis for the goals of student learning success. However, according to Syahruddin and Suyuti (2016) physical education has not yet fully succeeded in developing students' abilities and skills, both of physically, mentally and intellectually. One of the main problems is the lack of quality physical education teachers in schools.

From this theoretical study, it is found that in teaching physical education in schools it is necessary to apply attractive teaching methods in order to get the attention of students to follow every instruction given by the teacher and motor ability is a supporting indicator in the mastery of all movement skills taught by the teacher as a new skill that must mastered especially in the long jump teaching material taught in physical education material in schools. Thus, in this case the researcher wants to find out more about the relationship between these research variables in order to find findings that can be applied in future school teaching. 


\section{METHODS}

The experimental method used is a $2 \times 2$ factorial design, with the analysis technique of variance using the ANOVA requirement test, in the form of a normality test with the Liliefors test and the homogeneity test for each variance with the Bartlet test with a significant level of $\alpha=0.05$, followed by Tukey's test on the four proposed research hypotheses. The population of this study are all 80 male students of class VIII SMP Negeri 17 Serang who are measured for the level of motor ability using the IOWA Brace Test (Nurhasan \& Hasanudin, 2014), proceed according to opinion Zulkifli, Yani, Kamarudin, Sasmarianto, Alficandra, \& Henjilito (2020) to determine the high and low category of a score, namely $27 \%$ for the upper limit and $27 \%$ for the lower limit by calculations using the Verducci formula with the percentage technique, as in the table 1 .

Table 1. Design of Factorial Research 2 × 2

\begin{tabular}{ccc}
\hline \multicolumn{1}{c}{ Teaching Method (MM) } & $\begin{array}{c}\text { Exercise Style } \\
\text { Motor Educability } \\
\text { (ME) }\end{array}$ & $\begin{array}{c}\text { Commando Style } \\
\left(\mathbf{M M}_{2}\right)\end{array}$ \\
\hline High $\left(\mathrm{ME}_{1}\right)$ & $\mathrm{MM}_{1} \mathrm{ME}_{1}$ & $\mathrm{MM}_{1} \mathrm{ME}_{2}$ \\
\hline Low $\left(\mathrm{ME}_{2}\right)$ & $\mathrm{MM}_{1} \mathrm{ME}_{2}$ & $\mathrm{MM}_{2} \mathrm{ME}_{2}$ \\
\hline
\end{tabular}

Note:

$\mathrm{MM}_{1} \mathrm{ME}_{1}$ : Group of training style teaching methods for students who have high motor ability in long jump skills. $\mathrm{MM}_{1} \mathrm{ME}_{2}$ : The command style teaching method group for students who have high motor ability in long jump skills. $\mathrm{MM}_{2} \mathrm{ME}_{1}$ : Group of training style teaching methods for students who have low motor ability in long jump skills $\mathrm{MM}_{2} \mathrm{ME}_{2}$ : The command style teaching method group for students who have low motor ability in long jump skills.

The sampling technique explains that this study divides the sample into two groups. Then based on the results of grouping, the number of samples for each sub-group MM1ME1, MM2ME1, MM1ME2, MM2ME2 amount to 20 students and two treatment groups are obtained, namely the group with the command style teaching method totaling 10 students and the teaching method for the exercise style totaling 10 students. Distribution of treatment sample grouping as listed in table 2.

Table 2. Grouping of Research Sample

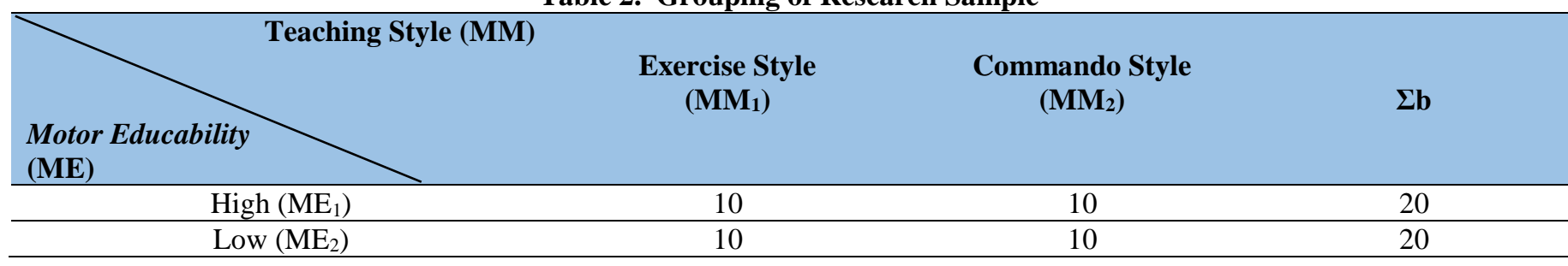

The research is conducted at SMP N 17 Serang in class VIII students. The study time is for eight weeks, with a training frequency of 2 (two) days per week, with a time of 2 x 45 minutes. The whole activity lasts for $16 \mathrm{x}$ meetings held in the intracurricular way. The learning material applied is the basic technique of long jump skills. At the beginning of the meeting, a preliminary test is carried out, then given treatment, and the last activity is to conduct a test for all sample members with a basic technical skill test of hanging style long jump. This long jump test instrument has been tested first and continued with a validation test by several athletic experts, namely the Banten regional training plate coach and the Serang City Platcab trainer and obtained a reliability of 0.70 which means good and this instrument is feasible to measure student skills.

\section{RESULT AND DISCUSSION}

Before the analysis of variance (Anava) is carried out, first the requirements analysis tests are carried out, namely (1) normality test; and (2) homogeneity test. Following are the results of the prerequisites for the description below: 


\section{Test of Normality}

The normality test for the improvement in long jump skills is carried out using the Liliefors test at the significant level $\alpha=0.05$, which can be seen in the table 3 .

Table 3. Test of Normality

\begin{tabular}{|c|c|c|c|c|}
\hline Group & $\mathbf{N}$ & $\mathbf{L}_{0}$ & $\mathbf{L}_{\mathbf{t}}$ & Conclusion \\
\hline $\mathbf{M M}_{1}$ & 20 & 0,090 & 0,190 & Normal \\
\hline $\mathbf{M M}_{2}$ & 20 & 0,118 & 0,190 & Normal \\
\hline $\mathrm{MM}_{1} \mathbf{M E}_{1}$ & 10 & 0,186 & 0,258 & Normal \\
\hline $\mathbf{M M}_{1} \mathbf{M E}_{2}$ & 10 & 0,123 & 0,258 & Normal \\
\hline $\mathbf{M M}_{2} \mathbf{M E}_{1}$ & 10 & 0,183 & 0,258 & Normal \\
\hline $\mathbf{M M}_{2} \mathbf{M E}_{2}$ & 10 & 0,142 & 0,258 & Normal \\
\hline
\end{tabular}

The results of the calculations in the table above, obtained Lo <Lt. Thus, it can be concluded that the sample comes from a normally distributed population.

\section{Test of Homogeneity}

Homogeneity test uses the Bartlett test with a significance level of $\alpha=0.05$. A summary of the results of the homogeneity test can be seen in table 4 .

Table 4. Test of Homogeneity

\begin{tabular}{lccccc}
\hline Group & Variance & $\begin{array}{c}\text { Compound } \\
\text { Variance }\end{array}$ & $\mathbf{X}_{\mathbf{h}}^{\mathbf{2}}$ & $\mathbf{X}_{\mathbf{t}}^{\mathbf{2}}$ & Conclusion \\
\hline $\mathbf{M M}_{\mathbf{1}} \mathbf{M E}_{\mathbf{1}}$ & 11.07 & 28.24 & 3.81 & 7,81 & Homogeneous \\
$\mathbf{M M}_{\mathbf{1}} \mathbf{M E}_{\mathbf{2}}$ & 27.61 & & & & \\
$\mathbf{M M}_{2} \mathbf{M E}_{\mathbf{1}}$ & 33.07 & & & & \\
$\mathbf{M M}_{2} \mathbf{M E}_{2}$ & 41.21 & & & \\
\hline
\end{tabular}

The results of the calculations in table 4 above, obtained $X 2 h=3.81<X 2 t=7.81$ So that Ho: accepted in the real level $\alpha=0.05$. Thus it can be concluded that the four populations have the same variance (homogeneous).

\section{Test of Hypotheses}

In the results of testing the first and second hypotheses, the researchers use two-way analysis techniques. For a summary of the research results, see table 5 .

Tabel 5. Summary of Research from Accounting Result of Two Lanes

\begin{tabular}{|c|c|c|c|c|c|}
\hline Source of Variance & Dk & JK & KT & Fo & $\mathbf{F t}$ \\
\hline Average & 1 & 79388.10 & 79388.10 & & \\
\hline \multicolumn{6}{|l|}{ Treatment } \\
\hline $\mathrm{MM}_{1}$ & 1 & 176.40 & 176.40 & $6.25 *$ & 4,09 \\
\hline $\mathrm{ME}_{1}$ & 1 & 122.50 & 122.50 & $4.34 *$ & 4,09 \\
\hline $\mathrm{MM}_{1} \mathrm{ME}_{1}$ & 1 & 761.30 & 761.30 & $26.96^{*}$ & 4,09 \\
\hline Mistake (E) & 36 & 1016.60 & 28.24 & & \\
\hline Total & 40 & & & & \\
\hline
\end{tabular}

\section{1) Differences in the Effect of Exercise Teaching Styles and Command Teaching Styles on Overall Long Jump Skills}

There is a difference between the training teaching style and the commando teaching style towards improving long jump skills, based on the prerequisites $\mathrm{Fo}>\mathrm{Ft}$, so that Ho is rejected, and $\mathrm{Fo}=6.25$ and $\mathrm{Ft}=$ 4.09 are obtained. With the conclusion that the increase in long jump skills using the exercise teaching style $(X=105.73 ; s=14.05)$ is better than the command teaching style $(X=97.07 ; s=12.16)$. 
2) The Differences of the Effect of Exercise Teaching Style and Command Teaching Style on Long Jump Skills for the High Educability Motor Group

Teaching style has an effect on improving group long jump skills with high motor ability. Furthermore, the test is carried out using the Tukey test as in table 6 of the following significant tests:

Table 6. Group Comparison of Exercise Teaching Styles and Command Teaching Styles in Students with High Motor Educability

\begin{tabular}{ccccc}
\hline No & Compared Group & Q accounting & Q table & Note \\
\hline 1 & $\mathrm{MM}_{1} \mathrm{ME}_{1}$ with $\mathrm{MM}_{2} \mathrm{M}$ & 6,55 & 2,26 & Significant \\
\hline
\end{tabular}

From the table above we get Qo $=6.55$ and $\mathrm{Qt}=2.26$. Because Qo> Qt, so Ho is rejected, and it can be interpreted that there is an increase in long jump skills and it can be concluded that students who have high motor ability using the exercise teaching style $(X=116.47 ; \mathrm{s}=10.84)$ are better than the command teaching style. $(\mathrm{X}=96.00 ; \mathrm{s}=11.41)$ in the improvement of long jump skills.

\section{3) Differences in the Effect of Exercise Teaching Style and Command Teaching Style on Long Jump Skills for the Low Educability Motor Group}

Teaching style has an influence on improving long jump skills in the low motor ability group. This is evident from the results of further tests using the Tukey test as in table 7 of the following significant tests:

Table 7. Group Comparison of Exercise Teaching Styles and Command Teaching Styles in Students with Low Motor Educability

\begin{tabular}{lcccc}
\hline No & Compared Group & Q accounting & Q table & Note \\
\hline 2 & $\mathrm{MM}_{1} \mathrm{ME}_{2}$ with $\mathrm{MM}_{2} \mathrm{ME}_{2}$ & 1.55 & 2,26 & Not Significant \\
\hline
\end{tabular}

The low motor ability group and exercise teaching style (MM1 ME2) compared to the low motor ability and command teaching style (MM2 ME2) group, are obtained Qo $=1.55$ and Qt $=2.26$, Qo $<\mathrm{Qt}$, so that Ho is accepted. It can be concluded that students with low motor ability and using the command teaching style $(X=98.15 ; \mathrm{s}=13.40)$ are better than the exercise teaching style $(X=94.98 ; \mathrm{s}=6.54)$ in improving long jump skills.

\section{4) The Interaction between Teaching Style and Motor Educability on Improving Long Jump Skills}

The results of the analysis of variance regarding the interaction between teaching style and motor ability to improve long jump skills show that the value of the calculation of FO interaction $(\mathrm{FAB})=26.96$ and $\mathrm{F}$ table $=4.09$. It can be concluded that there is an interaction between learning styles and motor ability to long jump skills.

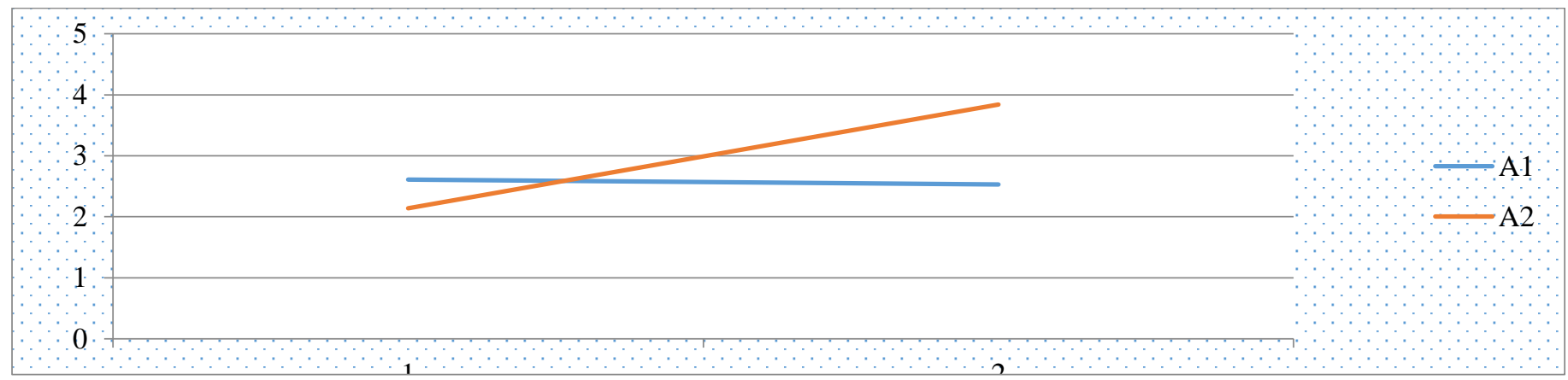

Picture 1. The Interaction between Teaching Style and Motor Educability on Improving Long Jump Skills 
Note:

MM : Teaching Style

ME : Motor educability

In accordance with the objectives of this study, namely (1) to determine the difference in the effect between the teaching method of training style and the command style teaching method on the learning outcomes of long jump skills, (2) to determine the difference in the effect of the teaching training method with the command teaching method on the learning outcomes of jumping skills. for high motor ability, (3) to find out the difference in the effect between the training style teaching method and the command style teaching method for students who have low motor ability in the long jump skills learning outcomes, and (4) to determine the interaction between the teaching method and the motor ability the results of learning long jump skills.

The results of testing the first hypothesis as a whole, there is a significant difference between the training style teaching method and the command style teaching method on the long jump skills learning outcomes. In other words, the results of learning long jump skills using exercise teaching styles are better than command teaching styles, this means that the first hypothesis has different teaching styles on the long jump skills learning outcomes that have been tested.

The second test results for students who have high motor ability, the exercise teaching method is better than the command teaching method on the long jump skills learning outcomes. High motor ability ability possessed by students, is a potential if honed will be able to produce maximum results. In accordance with the opinion Sumantri et al., (2016) which states that it is because of the motivation for students to complete or master a material, and is supported by the characteristics of the teaching style of the exercise itself where students carry out movements / activities repeatedly (drill) as an effort to gain skills in performing long jump skills. The potential quality of motor ability will provide an overview of a person's ability to learn new movements easily.

Testing the third hypothesis there is no significant difference between the training style teaching method and the command style teaching method for students who have low motor ability in the long jump skills learning outcomes. The commando learning style had a higher average score for the low motor ability group. So that the two learning styles have the same or balanced effect on improving long jump skills. In line with the findings of previous relevant research by Putra, Asim, and Hariyanto (2017) that is, the command style teaching has a significant effect on students' interest in learning.

The third hypothesis shows that it cannot be verified because it has not been supported by empirical data in the field. That way, it is necessary to discuss the various possibilities that cause the hypothesis to be invalid. The possibilities that occur are as follows: (1) the sample activity of students are doing other sports activities outside the treatment given, because the sample is 17 Serang State Junior High School (SMP) students who also follow other subjects, (2) the uncontrolled element of motivation is the possibility of influencing during the teaching process and (3) Interest. As concluded in the research conducted by Andriani and Rasto (2019) students' learning outcomes can be improved through increased interest, which means that if someone has an interest in an activity, then he will be more serious about doing that activity.

The fourth hypothesis shows that there is an interaction between the teaching method and the motor ability of the long jump skills learning outcomes. This means that to improve learning outcomes long jump skills not only by using a teaching style, but also determined by how the motor ability of students has, in accordance with the results of research from (Sumantri et al., 2016).

Overall, the exercise teaching style has a better effect than the commando teaching style. Meanwhile, those who have high motor ability should choose an exercise teaching style if they want to improve their long jump skills. Meanwhile, those who have low motor ability can do both exercises to improve their long jump skills, but it tends to be better if they use a commando teaching style. 


\section{CONCLUSION}

From the results of the research and hypothesis testing, the overall results of this study concludes that the exercise teaching style is better than the commando teaching style. For students who have high motor ability, it is better to use practice teaching styles to improve their long jump skills, if they want to improve their long jump skills. Students who have low motor ability can apply both exercises to improve their long jump skills. There is an interaction between teaching style and motor ability to long jump skills. One of the limitations of this study is that there are psychological factors that influence the results of the study, such as: motivation, interests, talents and the presence of physical factors that affect the results of the study, such as: height, strength, explosive power and coordination. This research needs to be followed up in the future so that it can provide input to teachers and researchers, if you want to measure the ability of motor ability in long jump learning, you can use the exercise teaching method in order to get maximum results.

\section{REFERENCES}

Agam, G. A., Rahayu, S., \& Rifai, A. (2016). Pengaruh gaya mengajar guided discovery dan tingkat motor educability terhadap hasil belajar pencak silat. Journal of Physical Education and Sports, 5(2), 134139. https://doi.org/10.15294/JPES.V5I2.13452

Andriani, R., \& Rasto, R. (2019). Motivasi belajar sebagai determinan hasil belajar siswa. Jurnal Pendidikan Manajemen Perkantoran, 4(1), 128-135. https://doi.org/10.17509/jpm.v4i1.14958

Aryanti, N. E. (2019). Studi korelasional antara motor educability, feedback, dan percaya diri dengan keterampilan dribbling instep of the foot siswa putra ekstrakurikuler sepakbola SMPN 29 Jakarta Tahun 2013. Jurnal Ilmiah Sport Coaching and Education, 3(1), 51-64.

Candra, R. D., \& Hidayah, T. (2015). Pengaruh metode latihan dan kemampuan motor educability terhadap hasil latihan teknik dasar sepakbola. Journal of Physical Education and Sports, 4(2). 159-164. https://doi.org/10.15294/JPES.V4I2.9888

Fallo, H. I. S. (2016). Upaya meningkatkan keterampilan smash permainan bola voli melalui pembelajaran gaya komando. Jurnal Pendidikan Olah Raga, 5(1), 10-19.

Huda, D. (2012). Sumbangan kecepatan, berat badan, daya ledak terhadap lompat jauh. JSSF (Journal of Sport Science and Fitness), 1(1), 1-6. https://doi.org/10.15294/JSSF.V1I1.212

Imansyah, F. (2019). Pengaruh metode inklusi menggunakan media pembelajaran dan tingkat motor educability terhadap hasil keterampilan belajar renang gaya dada pada mahasiswa jurusan pendidikan olahraga. Seminar Nasional Olahraga. Universitas PGRI Palembang.

Iswandi, F., Kaswari, K., \& Purnomo, E. (2013). Hubungan sprint dan daya ledak otot tungkai terhadap hasil lompat jauh gaya jongkok. Jurnal Pendidikan dan Pembelajaran Khatulistiwa, 2(4), 1-10.

Juniar, D. T., \& Iskandar, T. (2018). Pengaruh gaya mengajar komando dan motor ability rendah terhadap hasil belajar tendangan dolyo chagi taekwondo. JOSSAE: Journal of Sport Science and Education, 2(2), 42. https://doi.org/10.26740/jossae.v2n2.p42-45

Nurhasan, H., \& Hasanudin, C. D. (2014). Modul tes dan pengukuran keolahragaan. Bandung: Fakultas Pendidikan Olahraga dan Kesehatan UPI.

Paturusi, A. (2012). Manajemen pendidikan jasmani dan olahraga. Jakarta: Rineka Cipta. 
Putra, H. B., Asim, A., \& Hariyanto, E. (2017). Perbedaan pengaruh gaya mengajar komando dengan gaya mengajar latihan terhadap minat peserta didik pada pembelajaran permainan bola voli kelas $\mathrm{X}$ Madrasah. Gelanggang Pendidikan Jasmani Indonesia, 1(2), 252-261. http://dx.doi.org/10.17977/um040v1i2p252-261

Rahayu, E. T. (2013). Strategi pembelajaran pendidikan jasmani. Bandung: Alfabeta.

Rahayu, P., Rahayu, T., \& RC, A. R. (2017). Pengaruh gaya mengajar latihan dan koordinasi mata tangan terhadap hasil pembelajaran dribbling bola basket. Journal of Physical Education and Sports, 6(2), 186-192. http://dx.doi.org/10.15294/JPES.V6I2.17394

Rizal, B. T., \& Kasriman, K. (2020). Pengaruh gaya mengajar dan koordinasi mata tangan terhadap keterampilan smash bola voli. Jurnal MAENPO: Jurnal Pendidikan Jasmani Kesehatan dan Rekreasi, 10(2), 72-83. https://doi.org/10.35194/jm.v10i2.1065

Sujana, R., Muhtar, T., \& Nuryadi. (2014). Pengaruh pendekatan pembelajaran dan motor educability terhadap hasil belajar teknik dasar dan keterampilan bermain sepakbola. Edusentris, 1(3), 260-274. https://doi.org/10.17509/edusentris.v1i3.150

Sumantri, R. J., Sulaiman, S., \& Nasuka, N. (2016). Pengaruh media gaya mengajar latihan dan tingkat motor educability terhadap hasil belajar pencak silat. Journal of Physical Education and Sports, 5(2), 127-133. https://doi.org/10.15294/JPES.V5I2.13449

Sutikno, S. (2014). Metode dan Model-model Pembelajaran. Lombok: Holistica.

Syahruddin, S., \& Suyuti, A. (2016). Pengaruh gaya mengajar latihan dan gaya mengajar komando terhadap keterampilan passing atas bola voli. Jurnal Pedagogik Olahraga, 2(1), 11-22. https://doi.org/10.22245/jpor.v2i1.4505

Zulkifli., Yani, A., Kamarudin., Sasmarianto., Alficandra., \& Henjilito, R. (2020). Pengaruh dua gaya mengajar mosston dan dukungan motor ability mahasiswa terhadap hasil belajar teknik dasar sepak takraw. Journal Sport Area, 5(1), 51-64. https://doi.org/10.25299/sportarea.2020.vol5(1).4693 